\title{
KAN NEDERLAND WORDEN OPGEWEKT OM HET SURINAAMSCHE BINNENLAND TE LATEN EXPLOREEREN?
}

DOOR

\author{
W. R. MENKMAN
}

Als lid der redactie van dit tijdschrift kreeg ik inzage van het artikel van den Heer L. C. Prey „De waarde van vliegtuigen voor Suriname", voordat dit geplaatst werd. De lezing deed bij mij de hierboven staande vraag rijzen en ik zag geen reden waarom ik haar niet stellen zou, heet van de naald en eveneens in De WestIndische Gids. Mij dunkt, zelfs wanneer de beide artikelen in hetzelfde nummer verschijnen, kan er eigenlijk geen bezwaar tegen bestaan dat ik van mijn voorwetenschap gebruik maak.

De oud-administrateur van financiën roert een punt aan dat ook naar mijn meening van veel belang is, maar ik had zoo gaarne gezien dat hij vóórop had gesteld wat primair is.

Het spreekt van zelf, dat in Suriname, waar de uit de 17e en 18e eeuw dagteekenende bedrijven al zóó lang niet meer rendeeren, een onderzoek naar de mogelijkheden welke het land overigens - en dat beteekent buiten de z.g. cultuurzone - misschien nog biedt niet nu pas urgent is geworden, maar dat al veel eerder was. En even van zelf sprekend is het dat, wanneer een zoodanig onderzoek alsnog ter hand wordt genomen, daarbij gebruik zal worden gemaakt van de modernste hulpmiddelen, waartoe tegenwoordig ongetwijfeld het vliegtuig behoort.

Ik zie als resultaat van het artikel van den Heer Prey reeds een Kamerlid opstaan en de vraag tot de Regeering richten of wij thans Suriname's binnenland niet zouden gaan exploreeren, nu het blijkbaar mogelijk is daartoe vliegtuigen te gebruiken. Maar óók hoor ik reeds het antwoord van de groene tafel, dat, wanneer er mocht worden overgegaan tot een onderzoek naar de gesteldheid van het Surinaamsche binnenland, daarbij zeker een zoo ruim mogelijk gebruik zal worden gemaakt van vliegtuigen; waarmede dan de zaak weder finaal doodgepraat zal zijn. Wij

West-Indische Gids XVI 
kennen die eenigszins lukraak gestelde vragen, waarin het antwoord waarmede de Regeering voor het oogenblik volstaan kan, eigenlijk al opgesloten ligt.

Reeds vijftien jaar geleden bepleitte Abendanon de noodzakelijkheid eener economische inventarisatie van Suriname en hij noemde daarbij het vliegtuig als een modern hulpmiddel, dat den arbeid zou kunnen verlichten. Inderdaad, Nederland moet er eerst van overtuigd zijn dat onderzocht behoort te worden of het binnenland van Suriname waardeloos is of niet, dat is het primaire; niemand zal de diensten welke het vliegtuig bij de exploratie zou kunnen bewijzen, verwaarloozen of onderschatten.

De Heer Prey noemt het rapport van 1930 der studie commissie van de K.L.M. en komt terecht tot de conclusie dat aan dat rapport geen bijzondere waarde mag worden toegekend, met betrekking tot de kwestie der economische verkenning. Abendanon's zooveel oudere artikel in De West-Indische Gids echter vergeet onze auteur en dat is in één opzicht jammer. Het zal nu misschien aan de aandacht van sommige lezers ontsnappen dat de waarde van het vliegtuig voor economische opsporingsdoeleinden onmiddellijk na den wereldoorlog is erkend en dat er dus met betrekking tot Suriname volstrekt niet alleen maar gewacht is op een middel waarmede men sneller, veiliger en goedkooper in het binnenland kon doordringen dan op de oude manier. Overal waar men de noodzakelijkheid inzag om de tot dusver slecht toegankelijke wildernis te verbinden met de bewoonde wereld, heeft men zich van het vliegtuig bediend, zoodra men over dit hulpmiddel beschikte en meende erop te kunnen vertrouwen. Canada heeft een luchtvaartstatistiek welke met het jaar 1923 aanvangt, wat niet zeggen wil dat er al niet eerder is gevlogen, in Australisch Nieuw-Guinea kwam in 1926 de goudindustrie op en daardoor tevens de luchtvaart. Dat alles kan men in handboeken nazien en is dus niets nieuws. Of men heeft den arbeid van hen die reeds in het binnenland werkten veiliger, aangenamer en productiever willen maken, ò zijn geographische kennis van dat binnenland willen uitbreiden, of er naar nieuwe, tot dusver onbekende, of slechts vermoedelijk aanwezige rijkdommen willen zoeken. Waarom heeft men in Suriname niets van dit alles gedaan? Natuurlijk omdat men het niet noodig achtte, of er de uitgaven niet voor over had.

Dat een amateur uit Paramaribo wegvliegt, naar de Raleighvallen (afstand rechtstreeks 160 K.M.), daar wat rondkuiert en met etenstijd weer thuis is, zal niemand verbijsterend vinden, 
gegeven de bekende snelheid van vliegtuigen en de gunstige omstandigheden in Suriname. De vraag is slechts welke aanleiding er voor ondernemers kan bestaan, om op goed geluk vliegexpedities te bekostigen naar het binnenland van Suriname, zoo lang er geen aanwijzingen zijn betreffende het voorkomen van waardevolle bovengrondsche of ondergrondsche bodemproducten, expedities waaraan overigens wellicht heel wat meer zou vastzitten dan aan de uitstapjes van Amerikaansche millionairsdochters.

Sedert 1667 is Suriname Nederlandsch gebied en reeds in 1670 lezen wij dat eenige kolonisten de vallen overtrokken, ter achtervolging van indianen; die kolonisten zullen daarbij wel niet door boschnegers zijn geholpen. Wat is er sedert gedaan, ter verkenning van het binnenland? In de $18 \mathrm{e}$ eeuw achtervolgde men de marrons en in het begin der 20e werden ettelijke zeer verdienstelijke, maar grootendeels puur wetenschappelijke tochten gemaakt, waarvan de resultaten niet in ruime mate hebben bijgedragen - en ook niet konden bijdragen - tot de economische inventarisatie, waarover indertijd Ir. Abendanon schreef.

Wie zal het initiatief nemen tot het verrichten - van overheidswege - eener dergelijke inventarisatie, natuurlijk met gebruik making, zooveel mogelijk, van vliegtuigen? De Gouverneurs brengen in den regel bij hun ambtsaanvaarding geen speciale kennis van het land - laat staan van het binnenland mede en hun bestuursperioden zijn meestal niet van langen duur; een deskundig geleide dienst belast met al hetgeen het onderzoek en de ontwikkeling van het binnenland aangaat, is er niet in Suriname. Elke basis om iets in de gewenschte richting te beginnen ontbreekt dus. Toch lijkt het niet te boud gesproken, dat dit onderzoek en die ontwikkeling tot de Overheidstaak behooren. Toezien op en leiding geven aan het uit eigen beweging te voorschijn gekomen particuliere initiatief, is nu eenmaal niet het maximum van hetgeen van de Surinaamsche Overheid kan worden verwacht, omdat dit particuliere initiatief afwezig is en ook afwezig zal blijven, zoolang niet bij toeval een particulier in het binnenland iets vindt dat de moeite waard schijnt. Ook hier weder vertoont zich de beruchte Surinaamsche vicieuze cirkel; het Gouvernement onthoudt zich, zoolang particuliere ondernemingen geen belangstelling toonen en de ondernemingsgeest blijft ontbreken, zoolang het Gouvernement geen winstbelovend arbeidsveld weet aan te wijzen.

Gegeven de financieele verhouding tusschen moederland en ge- 
west en gegeven ook de positie van het Bestuur tegenover de Regeering, bestaat er niet de minste kans dat een Gouverneur uit eigen beweging gelden op de Surinaamsche begrooting zal brengen voor de installatie van hetgeen allereerst noodig zou zijn, n.l. een specialen opsporingsdienst, met technisch personeel en met materieele outillage. Ook zal wel geen Minister spontaan het initiatief nemen tot een maatregel welke voorloopig geen ander gevolg zou hebben dan al weer een verhooging der „uitgaven ten behoeve van Suriname".

Ergo, zouden de Staten-Generaal zich de zaak moeten aantrekken. De kans daarop lijkt uiterst gering; pas is er in de Eerste Kamer een Surinaamsche begrooting aangenomen, zonder mondelinge behandeling, omdat er geen tijd meer was. Inderdaad, nog eens wat heen en weer te praten over sinaasappelen en bacoven, zou heel weinig nut hebben kunnen stichten.

Moet het koloniale beleid óók gericht zijn op de economische ontwikkeling der overzeesche gewesten, dan zijn, wat Suriname betreft, geldelijke offers, door het moederland te brengen, onvermijdelijk; dit zou zelfs het geval zijn wanneer dit gebiedsdeel het nog juist zonder subsidie kon stellen, om de gewone bestuursdiensten te bekostigen.

Nederland heeft zoodanige offers ook herhaaldelijk gebracht, doch daarbij steeds de illusie willen behouden van niet te geven, maar te leenen, of den grondslag te leggen voor een opbloei, welke Suriname op korten termijn financieel van het moederland onafhankelijk zou maken. De uitgaven, noodig voor een deugdelijk onderzoek naar de ontwikkelingsmogelijkheden van het Surinaamsche binnenland, zouden in een ruimer en algemeener oogmerk haar rechtvaardiging moeten vinden.

Zonder ernstigen tegenstand zijn tot dusver - en volstrekt niet uitsluitend in dagen van moederlandschen voorspoed maatregelen goedgekeurd ten behoeve van Suriname, wanneer daarmede uitgaven in ééns gemoeid waren en niet een permanente of langdurige verhooging van het jaarlijksche tekort. Nog maar enkele jaren geleden b.v. werd een niet onaanzienlijke bijdrage uit de Nederlandsche schatkist beschikbaar gesteld ten behoeve van het mechanische rijstbedrijf in Suriname, hoewel de motiveering geenszins de overtuiging vermocht te geven dat de economische versterking der Surinaamsche gemeenschap het uitsluitende of het voornaamste doel was. De overweging dat het slechts ging om een vooraf gefixeerd bedrag, heeft waarschijnlijk doen heenstappen over het bezwaar dat het ontstaan van een 
nieuw Europeesch bedrijf - zelfs van een bloeiend Europeesch bedrijf - op landbouwgebied, het Suriname van tegenwoordig niet in belangrijke mate vooruit kan helpen. Of misschien wordt nog niet algemeen ingezien dat Suriname reeds lang heeft opgehouden een exploitatiekolonie te zijn en dat ook niet opnieuw kan worden, ook al zou een in die richting loopende politiek nog bestaanbaar kunnen worden geacht.

Merkwaardig is het in dit verband dat het rijsthoeveplan, waarvoor ook slechts een bijdrage in ééns werd gevraagd en dan nog maar een kleine bijdrage, niet uit de openbare geldmiddelen wordt gesteund, hoewel het bij welslagen althans de kans biedt - men kan zooveel reserves maken als men wil - dat een nieuwe weg in de gewenschte richting wordt aangewezen. Onder de tegenwoordige omstandigheden zou één Surinaamsch middenstander die het als zelfstandig landbouwondernemer tot een behoorlijk bestaan zou brengen, een meer welkome verschijning zijn dan tien nieuwe Europeesche landbouwbedrijven, al dan niet gemechaniseerd.

Nieuwe plantagebedrijven in Suriname te helpen oprichten kan nimmer op zich zelf tot de taak der Overheid behooren; hoogstens kan het verantwoord zijn de oude op de been te houden, om erger te voorkomen. Overigens echter is steun aan den Surinaamschen landbouw slechts verdedigbaar voor zoover het geldt den inheemschen landbouw, dien dus waarbij de aanwezige Surinaamsche bevolking belang heeft.

Dat met betrekking tot de ontsluiting van het Surinaamsche binnenland geheel andere motieven behooren te gelden, spreekt van zelf. Wanneer het land rijkdommen in zijn schoot verbergt, dan moeten die ten bate van het gemeen ontgonnen worden; ook particuliere exploitatie zou aan de gemeenschap ten goede komen. Men zie naar Curaçao; de bevolking aldaar heeft bij olieindustrie en scheepvaart slechts arbeidsbelangen evenals voor de Javaansche bevolking de suikerindustrie slechts het middel was om geld te maken voor verrichten arbeid en andere bewezen diensten. De Europeesche en Amerikaansche bedrijven op $\mathrm{Cu}-$ raçao (en Aruba) hebben echter het volksinkomen aanzienlijk vergroot, ook al werken die bedrijven voor uitheemsche rekening. In Suriname kan het uitheemsche plantagebedrijf, gegeven de geheele constellatie van arbeidsvoorziening, immigratie en kolonisatie, noch met de Javasuikerindustrie, noch met het $\mathrm{Cu}$ raçaosche oliebedrijf op één lijn worden gesteld, met betrekking tot het economisch leven van het gewest waar uitheemsche onder- 
nemingen opereeren. Dit zou echter wèl het geval zijn ten aanzien van die ondernemingen welke Suriname's binnenland zouden exploiteeren. Zij zouden de arbeidsgelegenheid verbeteren voor de reeds aanwezige bevolking en een grootere verspreiding dier bevolking over de enorme oppervlakte van het land in de hand werken. Men bedenke dat van de Surinaamsche bevolking circa de helft in den engeren zin „inboorlingen” zijn en in den ruimeren zin een veel grooter percentage, dat het aantal gecontracteerde of niet gecontracteerde plantage arbeiders nog maar gering is en dat de rest der inwoners in de stad huist, waar weinig of niets te doen is, of kleinen landbouw beoefent, met een zeer poover financieel resultaat.

Wat er ook ver van de stad op het gebied van hygiëne enz. kan worden bereikt, bewijst Moengo; overigens zal natuurlijk niemand zich de enorme moeilijkheden ontveinzen welke aan een werkelijke occupatie van het binnenland zouden kunnen blijken verbonden te zijn.

Evenmin als toen Ir. E. C. Abendanon zijn bijdrage leverde aan den eersten jaargang van De West-Indische Gids kan er thans eenige waarschijnlijkheid aanwezig geacht worden dat Nederland zich op eens op zal maken om het Surinaamsche binnenland economisch te gaan verkennen; allicht staan de kansen thans ongunstiger dan toen.

Desniettemin kan het toch nuttig zijn er nog eens de aandacht op te vestigen dat het veelzijdige Suriname probleem ten deele ook is het probleem van het binnenland.

Amsterdam, Mei 1934. 